\title{
Study on the Vulnerability of Agricultural Productivity to Climate Change in Mahabubnagar District, Andhra Pradesh
}

\author{
Valli Manickam, K.Shanti Sree, and Iyyanki V. Murali Krishna
}

\begin{abstract}
Agriculture is one of the most sensitive sectors to climate change, and any degree of change will bring potential or significant impact to agricultural productivity. Compared to other sectors like water resources, forests and other natural ecosystems, agriculture is the most vulnerable to climate change. In this background the present study is undertaken to analyze the changes in rainfall and temperature over a period of two decades and its possible impacts on agricultural productivity at district and mandal / block level in Mahabubnagar district of Andhra Pradesh. The analysis included statistical evaluation of rainfall, temperature and other meteorological parameters. Statistical software's were used to perform regression and cluster analysis and to calculate the $R^{2}$ values which varied from nil to 0.25 in the six mandals selected for the study. Based on these analyses an assessment of the agricultural productivity of the area was made and compared with the agricultural Gross Domestic Product(GDP) of the Mahabubnagar region using Ordinary Least Square (OLS) model. The finding indicate $R^{2}$ values without GDP varies from 0.07 to 0.31 for the three crops where as when the GDP values are considered $R^{2}$ values are from 0.29 to 0.72 .
\end{abstract}

Index Terms-Agricultural GDP, Agro-climatic regions, average linkage method, ordinary least square model.

\section{INTRODUCTION}

Over exploitation of fossil fuels due to increased anthropogenic activities has led to increase in atmospheric concentration of carbon dioxide, a Green House Gas (GHG) largely responsible for global warming. As per the IPCC report 2007, increasing concentration of atmospheric carbon dioxide $\left(\mathrm{CO}_{2}\right)$, concurrent changes in temperature and precipitation patterns are expected to affect many aspects of human activities[1]. Researchers and administrators are concerned with the potential damages that may arise in future from climate change impacts on agriculture, since those are expected to affect domestic and international policies, trading pattern, resource use, and food security.

The higher temperature could have adverse impacts on crop yields. At the same time, higher rainfall could enhance growing period duration [2]. All such conflicting factors should be taken into consideration while assessing the climate sensitivity of agriculture. Climate change is expected to influence the agricultural yield in different

Manuscript received July 6, 2012; revised November 29, 2012. This study was conducted as part of the research project, sponsored by Ministry of Environment and Forests, Government of India, New Delhi.

The authors are with Environment Area, Administrative Staff College of India, Khairtabad, Hyderabad, Andhra Pradesh, India (e-mail: valli.manickam@gmail.com; iiyanki@icorg.org). manner under different agro-climatic conditions. Indian agriculture is fundamentally dependent on weather for higher productivity and most of the states in the country are largely dependent on rainfall for irrigation which is also true for the district of Mahabubnagar. Any change in rainfall patterns poses a serious threat to agriculture, and therefore to the country's economy and food security. Agriculture will be adversely affected not only by an increase or decrease in the overall amounts of rainfall, but also by shifts in the timing of the rainfall [3]. In this context the present study of the impact of meteorological parameters on agricultural productivity and its vulnerability to changes in the climatic conditions was undertaken.

\section{MAterials AND MethodS}

\section{A. Study Area}

Mahabubnagar is the second largest district in Andhra Pradesh in terms of area covered. The district is divided into 64 mandals. It is located between $15^{\circ} 55^{\prime}$ and $17^{\circ} 20^{\prime}$ North, latitudes and $77^{\circ} 15^{\prime}$ and $79^{\circ} 15^{\prime}$ East, longitudes. The area of the district is 18,432 sq. kms. Agriculture is the main occupation and is primarily crops of paddy, jowar, groundnut, castor, cotton. Mahabubnagar district has two agro-climatic zones namely Southern Telangana Zone and Scarce Rainfall Zone. The distribution of the agro-climatic regions in the district is shown in Fig.1. The figure also identifies the mandals selected for in depth analysis of the impact of climate on agricultural productivity.

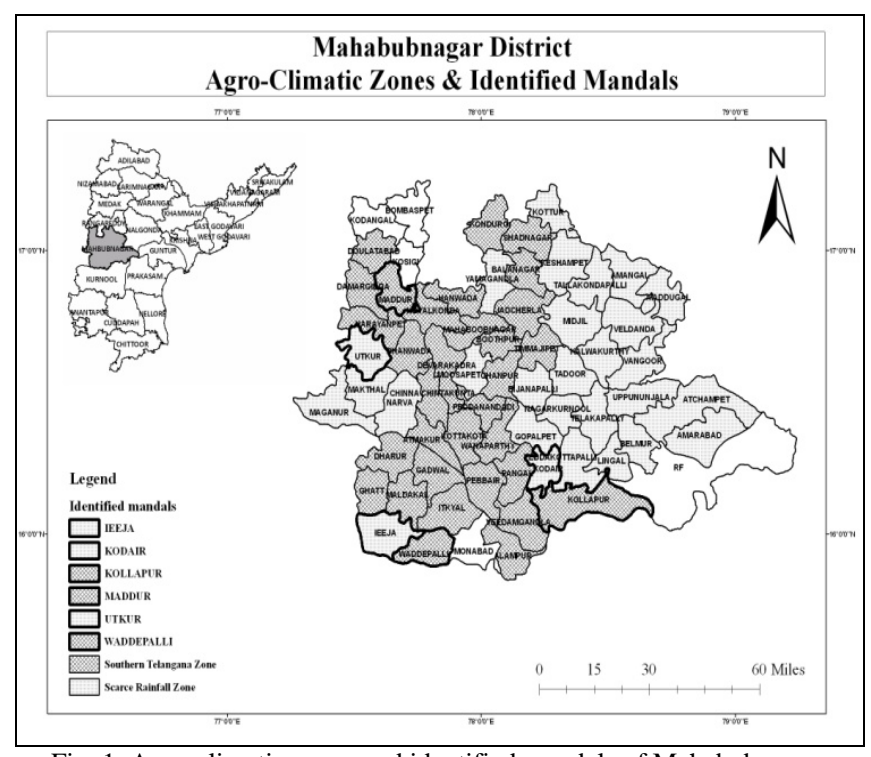

Fig. 1. Agro-climatic zones and identified mandals of Mahabubnagar district 


\section{B. Methodology}

The study of the meteorological parameters and its impact on agricultural productivity in the district of Mahabubnagar is carried out both at district and at mandal / block level. The study includes analysis of district level meteorological, agricultural and socio-economic data for a period of 20 years. The statistical analysis pertaining to average monthly, seasonal (June to October) and annual rainfall for each mandal of the district has been computed using SYSTAT 7.0.1 software. Linear Regression test was done to identify the existence of any trend or persistence in the rainfall series. After a preliminary analysis of the data, the mandals most vulnerable are analyzed and studied in detail. The Average Linkage method of clustering was carried out for identifying the distinct clusters of rainfall as well as crop yields. Ordinary Least Square model (OLS) was used to identify the correlation between the agricultural GDP and prices. Arc GIS 9.1 software is used for mapping and carrying out the spatial data analysis at district and mandal level to understand the spatial distribution of the various meteorological parameters and its impact on agricultural productivity.

\section{REsults AND DiscussiOnS}

The district is divided distinctly into two zones Southern Telangana Zone which consists of 36 mandals which has an annual rainfall between 700-900 mm and Scarce Rainfall Zone under which 28 mandals are covered with an annual rainfall between $500-700 \mathrm{~mm}$. The meteorological parameters of temperature and rainfall are taken into consideration for this study analysis in these mandals of the district. In the case of temperature one station is collecting data from 1999 - 2008. The rainfall data is collected on a 24 hour basis in each mandal is analyzed during the period 1980 to 2008 . Trends for temperature in the region show no significant change in the maximum and minimum temperature. However detailed analysis of the temperature data shows erratic variations of the data in the maximum average temperature during the first half of the decade, and moving towards increasing trends from 2005 onwards. Earlier studies carried out have also shown that there is a definite relationship between temperature and agricultural productivity. In India an increase of $2{ }^{\circ} \mathrm{C}$ in temperature could decrease the rice yield by about 0.75 ton/ha (hectares) in the high yield areas; and $0.5^{\circ} \mathrm{C}$ increase in winter temperature would reduce wheat yield by 0.45 tons/ha [4]. Many parts of northern India show increase in minimum temperature by about $1^{\circ} \mathrm{C}$ in Rabi cropping season. However, mean temperatures are misleading as some of the individual regions could exhibit a larger variation with a larger impact on rabi crop production [5]. A study in Kerala has shown that for every one degree rise in temperature coupled with the decline in rice yield about 6\% [6]. This clearly indicates that temperature related studies are important to predict the agricultural productivity of crops in the region.

An analysis of the district level rainfall data for the period 1980 to 2008 was carried out. Fig. 2 shows the percentage deviation between the normal and the annual rainfall of the Mahabubnagar district from 1980 to 2008. There is a large deviation in the amount of rainfall recorded in the year 1983-1984 where it exceeds the normal rainfall of $604 \mathrm{~mm}$ to $948 \mathrm{~mm}$ showing $57.0 \%$ deviation. In the year $1986-1987$ the actual rainfall recorded is $209 \mathrm{~mm}$ which is lower than the normal rainfall showing $-65.3 \%$ deviations. The linear trend shows a decrease in the percentage deviation. From the above findings it is clear that there is a change in the rainfall patterns. The mandal level analysis of the rainfall data was carried out for the 64 mandals in the district for a period 1980 to 2008. It has been seen that there is significant deviations in the quantity of rainfall in the various mandals of the district. In Salem district of Tamil Nadu [7] the annual average rainfall distribution is very low in the study area and changes in rainfall patterns have occurred in study period of 1998-2007. The annual rainfall distribution pattern of Umiam, Meghalaya, India for the period of 27 years (1983-2009) in the region was erratic and has changed significantly during the last few years [8]. In the present study, the data showed considerable changes in rainfall patterns and to further understand the trends in the rainfall during various seasons a season wise break up analysis was carried out at mandal level. The season wise analysis helped to correlate with the agricultural patterns observed in the particular mandal of the district and thereby its impact on productivity. The analysis of the season wise break up has shown that the rainfall has predominantly occurred in the south west monsoon season. This season is contributing maximum water to the crops grown in the region. Similar studies have been carried out by researchers which show that south west monsoon (June to September) alone contributed $75 \%$ of annual rainfall and July was the rainiest month $(1117 \mathrm{~mm})$ with 27 rainy days throughout Kerala [9]. Across nine sites of Western Australia[10], growing season rainfall (May to October) decreased by an average of $11 \%$ and the sum of rainfall in June and July (June + July) decreased by 20\%. The Coefficients of Variance (CoV) for all the 64 mandals of the district were calculated and the maximum was observed in Kodair mandal (Scarce Rainfall Zone) while the minimum in Waddepalli mandal (Southern Telangana Zone). The top three mandals having high coefficient of variance in each agro climatic zones is selected for detailed analysis. The details of the percentage deviation, $\mathrm{R}^{2}$ values and the coefficient of variance for these mandals are given in Table I. The range of $\mathrm{R}^{2}$ values for the 6 mandals of the values for Ieeja is the highest recorded as 0.25 while all other values are ranging from 0.0 to 0.08 . Ieeja mandal falls in the scarce rainfall zone and it seems to be higher impact than the other selected mandals. Similar studies have been carried out at district and mandal / block by various experts in the country. On the all India scenario the time series of contribution of rainfall for each month towards the annual total rainfall for each year was prepared and observed the major shift in the rainfall pattern spatially and temporally during the recent years [11]. The Coimbatore district of Tamil Nadu shows an increase in annual rainfall variability from $21.16 \%$ to $52.28 \%$. The south, southwest and northwestern parts of the district experiences the heavy rainfall whereas the least rainfall was observed in east, northeast and southeastern parts of the district [12]. 


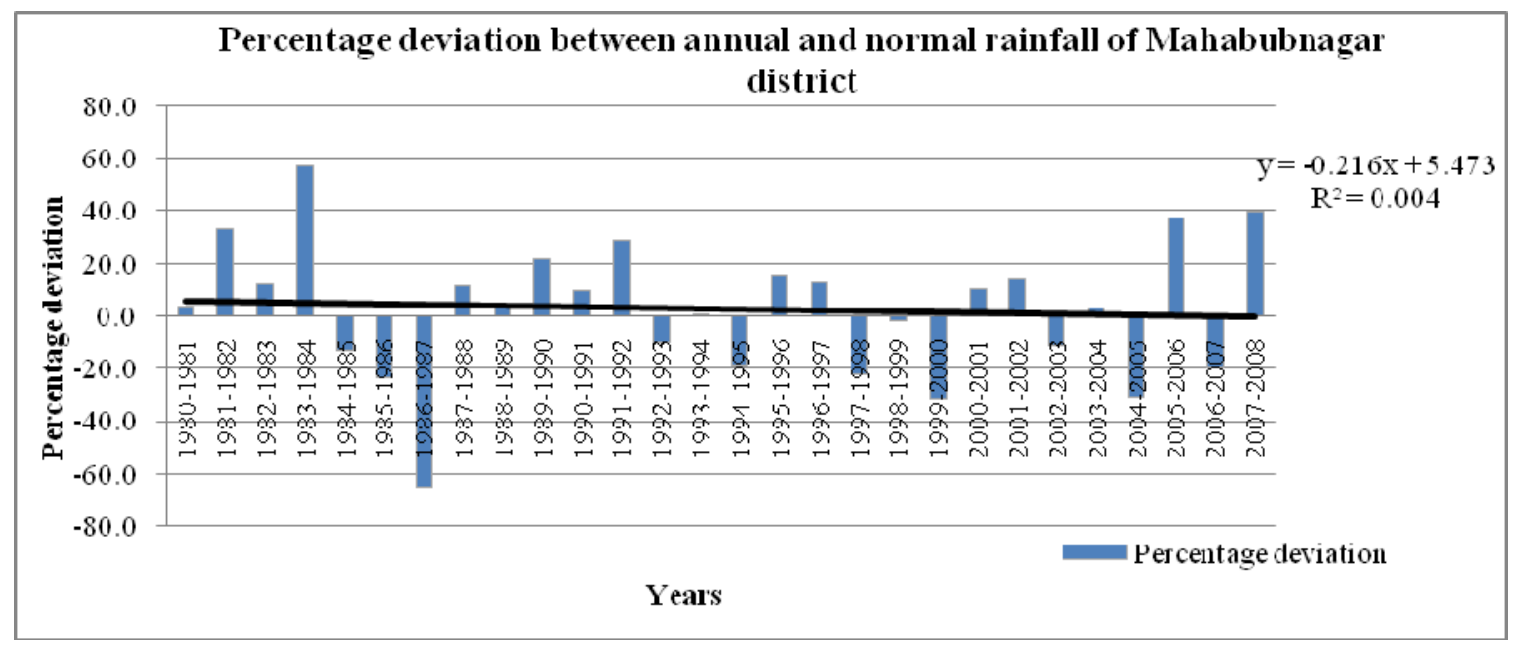

Fig. 2. Percentage deviation from Normal for the period of 1980-2008 in Mahabubnagar district

TABLE I: MANDALS CHOSEN FOR DETAILED ANALYSIS IN

\begin{tabular}{|c|c|c|c|c|c|c|}
\hline S.No & Mandals & $\begin{array}{c}\text { Annual } \\
\text { rainfall } \\
(\mathrm{mm})\end{array}$ & $\begin{array}{c}\text { Normal } \\
\text { rainfall } \\
(\mathrm{mm})\end{array}$ & CoV & $\begin{array}{l}\text { Percentage } \\
\text { Deviation }\end{array}$ & $\begin{array}{c}\mathrm{R}^{2} \\
\text { values }\end{array}$ \\
\hline zone & \multicolumn{7}{|c|}{ Scarce Rainfall Zone } \\
\hline 1 & Kodair & 556.3 & 510.4 & 56.3 & 5.1 & 0 \\
\hline 2 & Ieeja & 536.3 & 672.7 & 41.6 & -1.5 & 0.25 \\
\hline 3 & Utkoor & 558.9 & 663.4 & 33.7 & -16.2 & 0 \\
\hline zone & \multicolumn{7}{|c|}{ Southern Telangana Zone } \\
\hline 4 & Kollapur & 662.9 & 546.9 & 33.9 & -11.9 & 0.01 \\
\hline 5 & Maddur & 481.7 & 627.6 & 31.5 & -11 & 0.01 \\
\hline 6 & $\begin{array}{c}\text { Wadde- } \\
\text { palli }\end{array}$ & 590.7 & 544.3 & 26.6 & 8.5 & 0.08 \\
\hline
\end{tabular}

In order to understand the correlation between agricultural productivity and rainfall patterns in the district three crops viz., paddy, groundnut and cotton which are the major crops in the district, they are selected for analysis in the present study. The data was collected with reference to variation in yields for the period of 1993-2008. The correlation between the annual rainfall and the crop yield data are shown for the three crops in Fig. 3(a) to 3(c). For paddy as it can be seen in Fig. 3(a) there is no direct correlation between quantity of rainfall and the yield of the crop. From that we can imply that other sources of water may be used or the yield for the crop may be correlated by including other parameters like fertilizer inputs, other sources of water, pesticides and the acerage of crop being sown each year. The climate change is likely to be affected the agricultural yield per decade varied with geography and crop. There are negative yield responses to increased precipitation in many parts of the Norway. This negative yield effect could be caused by excess of soil moisture, which can be harmful to the plant growth or be related to reduce incoming sunlight [13]. The rainfall data for seasonal and weekly periods, weekly rainfall probabilities and yield prediction models using rainfall and productivity for the period 1960-1995 was analyzed and a significant positive correlation between yield and rainfall was observed for groundnut, pearlmillet and sorghum. The predictability of productivity of crops using seasonal rainfall is low at the centre for all the crops except groundnut which explained $56 \%$ variation in productivity [14].



Fig. 3.(a) Correlation between annual rainfall and crop yield of paddy for the period 1993-2008

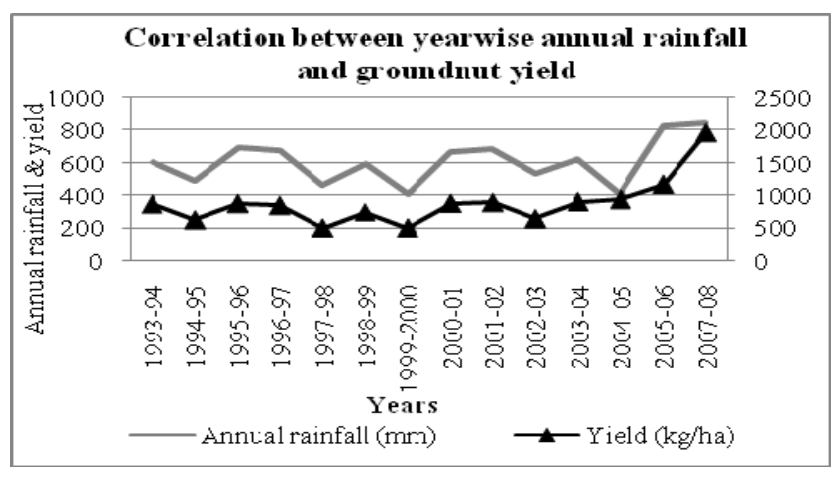

Fig. 3.(b) Correlation between annual rainfall and crop yield of groundnut for the period 1993-2008

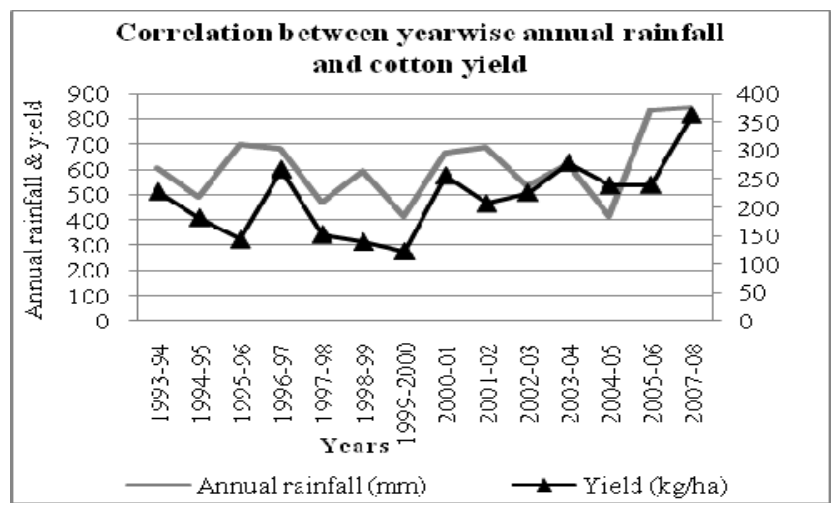

Fig. 3. (c) Correlation between annual rainfall and crop yield of cotton for the period 1993-2008 
Similarly from Fig. 3(b) it can be seen that a direct relation exists between the annual rainfall and the agricultural productivity, a decrease in rainfall has led to a decrease in the crop yield. An example of direct relation can be shown for the year 2007 - 08 in which an increase in rainfall has produced a higher yield. From Fig. 3(c) it can be seen that no correlation exists between the rainfall patterns and the crop yield for cotton. Irrespective of the quantity of annual rainfall the yield is almost remaining within the range of 123 to $364 \mathrm{~kg} / \mathrm{ha}$. It can be seen that crops like paddy and cotton have a mixed response to rainfall and needs further correlation with other parameters like micro nutrients, fertilizers etc., however for cotton the relationship seems to be direct. Based on the results for the crop yields and rainfall patterns a cluster analysis was carried out for the three crops. B.S.Kulkarni et al [15] shows a multivariate approach that identifies the pattern of rainfall during the entire crop growth periods of the crop season. The Average linkage method of clustering was carried out for identifying the distinct clusters of rainfall as well as crop yields. In this method, the objects (i.e., the $\mathrm{N}$ years of rainfall - crop yield data in the present case) are classified into distinct clusters on the basis of the relative distance between the objects, which measure the degree of closeness between them. Dendogram and hierarchical clustering between south west monsoon data, annual rainfall and yield of three crops (paddy, groundnut and cotton) were done. The cluster analysis provides useful information about the yield response range corresponding to the different rainfall patterns that are likely to occur during the crop growth season. The results from the cluster analysis confirm that the direct correlation between rainfall and crop yields is possible in the case of groundnut. In the case of paddy and cotton, no correlation exists between the rainfall patterns and the crop yield. From this we can entail that other sources of water may be used or the yield for the crop may be correlated by including other parameters like fertilizer inputs, other sources of water, insecticides/ pesticides and the acerage of crop being sown each year. Based on the cluster analysis and direct impact of rainfall on agricultural productivity it is clearly established that there is a relation between the productivity and climate of the region. It can be concluded that the agricultural productivity is vulnerable to the vagaries of temperature and rainfall.

Further correlation with the agricultural GDP and the prices for the same period of study was attempted. To understand the impact of weather variables on the agricultural GDP an analysis was carried out by using Ordinary Least Square model (OLS). The required data was collected for the period 1997-2007 and the relation between the prices of commodities along the years was carried out. The OLS model was used to estimate the $\mathrm{R}^{2}$ values and its significance was computed for 2 data sets (1) Prices, rainfall and production and (2) GDP, prices, rainfall and production. The results showed the R-square, Multiple-R, T-stat values and the same was presented in Table II. A similar study analyzed the impact of weather on commodity prices and measured the degree of weather risk inherent on commodity prices and consequent linkages to inflation, exchange rates and GDP by using ordinary least square and co-integration models. The study shows that there is high impact of rainfall over production and prices [16].

TABLE II: RESULTS OF ORDINARY LEAST SQUARE METHOD

\begin{tabular}{|c|c|c|c|c|c|c|c|}
\hline \multirow[b]{2}{*}{$\begin{array}{l}\text { Comm- } \\
\text { odities }\end{array}$} & \multirow[b]{2}{*}{$\begin{array}{l}\text { Obser- } \\
\text { vations }\end{array}$} & \multicolumn{3}{|c|}{$\begin{array}{l}\text { Prices, Index number, } \\
\text { Annual rainfall } \\
\end{array}$} & \multicolumn{3}{|c|}{$\begin{array}{l}\text { Prices, Index number, } \\
\text { Annual rainfall , GDP }\end{array}$} \\
\hline & & $\begin{array}{c}\text { Multiple } \\
\text { R }\end{array}$ & $\begin{array}{c}\mathrm{R} \\
\text { Square }\end{array}$ & $\begin{array}{c}\text { T - stat } \\
\text { inter- } \\
\text { cept }\end{array}$ & $\begin{array}{c}\text { Multiple } \\
\text { R }\end{array}$ & $\begin{array}{c}\mathrm{R} \\
\text { Square }\end{array}$ & $\begin{array}{c}\text { T - stat } \\
\text { inter- } \\
\text { cept }\end{array}$ \\
\hline Paddy & 11 & 0.40 & 0.16 & 3.76 & 0.85 & 0.72 & 3.46 \\
\hline $\begin{array}{c}\text { Ground } \\
\text { nut }\end{array}$ & 11 & 0.26 & 0.07 & 2.14 & 0.62 & 0.38 & 1.68 \\
\hline Cotton & 11 & 0.56 & 0.31 & 4.87 & 0.54 & 0.29 & 0.92 \\
\hline
\end{tabular}

\section{CONCLUSION}

In the present context of impact of climate change on agricultural productivity and GDP, the study was undertaken in Mahabubnagar district of Andhra Pradesh, which has 64 mandals. Analysis of rainfall, temperature and agricultural productivity was undertaken for a period of two decades at both mandal and district level. The maximum and minimum temperature data for the period 1999-2008 showed no significant change. There is a large deviation in the amount of rainfall recorded in the year 1983-1984 where it exceeds the normal rainfall of $604 \mathrm{~mm}$ to $948 \mathrm{~mm}$ showing $57 \%$ deviation. In the year $1986-1987$ the actual rainfall recorded is $209 \mathrm{~mm}$ which is lower than the normal rainfall showing $-65.3 \%$ deviation. The Coefficients of Variance (CoV) for all the 64 mandals of the district were calculated and the maximum was observed in Kodair mandal (Scarce Rainfall Zone) while the minimum in Waddepalli mandal (Southern Telangana Zone).The study shows that significant changes have occurred in the rainfall patterns. The $\mathrm{R}^{2}$ values varied from nil to 0.25 in the six mandals selected for the study. This has also had an impact on the productivity of paddy, groundnut and cotton in the region. Cluster analysis and OLS models were run to confirm the impact of climate change on agricultural productivity of paddy, cotton and groundnut which indicate a direct impact of rainfall on agricultural productivity for groundnut and mixed response for paddy and cotton. Hence it can be concluded that agricultural productivity and thereby agricultural GDP are vulnerable to vagaries of climate.

\section{REFERENCES}

[1] Intergovernmental Panel on Climate Change (IPCC) Report, Cambridge University Press, Cambridge, United Kingdom and New York, USA, 2007.

[2] Sushila Kaul, "Bio- economic modelling of climate change on crop production in India,” presented at Economic Modeling Conference, Moscow, September 12-14, 2007.

[3] Envis Newsletter, Envis centre, Environment Department, Government of Maharashtra, Mumbai, June to July,2010.

[4] S. K. Sinha and M. S. Swaminathan, "Deforestation, climate change and sustainable nutrition security: a case study of India," Climatic Change, vol. 19, pp. 201-209, September 1991.

[5] S. K. Sinha, S. M. Kulshreshtha, A. N. Purohit, and A. K. Singh, "Base paper - climate change and perspective for agriculture," National Academy of Agricultural Sciences, New Delhi, India, pp. 20, 1998.

[6] S. A. Saseendran, K. K. Singh, L. S. Rathore, S. V. Singh, and S. K. Sinha, "Effects of climate change on rice production in the tropical humid climate of Kerala India," Climatic Change, vol. 44, no. 4, pp. 495-514, March 2000. 
[7] B. Gurugnanam, M. Suresh, M. Vinoth, and S. Kumaravel, "High/low rainfall domain mapping using GIS at Salem district, Tamilnadu, India," Indian Journal of Science and Technology, vol. 3, no. 5, pp. 542-545, May 2010.

[8] P. K.Anup Das, B. U. Ghosh, D. P. Choudhury, G. C. Patel, S. V. Munda, N. Ngacha, and Pulakabha Chowdhury, "Climate change in northeast India: recent facts and events-worry for agricultural management," Workshop Proceedings: Impact of Climate Change on Agriculture, vol. XXXVIII-8/W3, ISPRS archives, Ahmedabad 2009.

[9] K. Kandiannan, C. K. Thankamani, and P. A. Mathew, "Analysis of rainfall of the high rainfall tract of northern agro-climatic zone of Kerala,” Journal of Spices and Aromatic Crops, vol. 17, no. 1, pp. 16-20, March 2008.

[10] Fulco Ludwig, P. Stephen, Milroy, and Senthold Asseng, "Impacts of recent climate change on wheat production systems in western Australia," Climatic Change, vol. 92, pp. 495-517, September 2008.

[11] P. Guhathakurta and M. Rajeevan, "Trends in the rainfall pattern over India,” Int. J. Climatology, vol. 28, pp. 1453-1469, November 2007.

[12] I. M. Rathod and S. Aruchamy, "Spatial analysis of rainfall variation in Coimbatore district Tamilnadu using GIS," International Journal of Geomatics and Geosciences, vol. 1, no. 2, 2010.

[13] M. Twena, A. Torvanger and B. Romstad, "Climate change impacts on agricultural productivity in Norway," CICERO Working Paper 2004:10, October 2004.

[14] D. R. Mehta, A. D. Kalola, D. A. Saradava, and A. S. Yusufzai, "Rainfall variability analysis and its impact on crop productivity- a case study," Indian J. Agrlc. Res., vol. 36, no. 1, pp. 29 - 33, 2002.

[15] B. S. Kulkarni, T. Sreenivasa Rao, and G. Krishna Kanth, "A study on association of combined effect of rainfall patterns on crop yields," J. Ind. Soc. Agril. Statist, vol. 58, no. 3, pp. 344-351, April 2004.

[16] Preeti Laddha, S. Agarwal, P. Kulkarni, and N. K. A. Murthy, "Weather risk, agro commodity prices and macroeconomic linkages: evidence from Indian scenario using co-integration model,” presented at the International Conference on Agribusiness and Food Industry in Developing Countries: Opportunities and Challenges, Indian Institute of Management, Luck now, August 10-12, 2007.

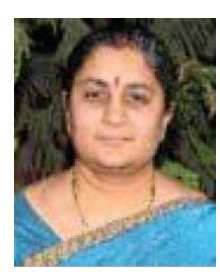

Valli Manickam was born in India, in 1969 who has her Ph.D in Environmental Science and Technology with Masters in both Computer Applications and Sciences, with over ten years of teaching experience in the field of environmental science (to post graduate students). She is currently Professor Chairperson, Environment Area, CEEUGID, ASCI.

Prior to joining ASCI, she has worked at Centre for Atmospheric Sciences and Weather Modification and at Centre for Environment, Jawaharlal Nehru Technological University, Hyderabad. She has executed a DST Women Scientist Project for Lake Remediation technologies. She has worked for a number of environmental projects and activities which include environmental impact assessment study for taking up industrial activity, study of lakes in and around Hyderabad, study of pollution in surface and ground waters, review of environmental statements, risk assessment, common effluent treatment plants, air pollution assessment studies, weather modification operations. She has developed software for the automation of the water and wastewater treatment systems and has also designed and developed a database for storage of the data during cloud seeding operations.

She has coauthored five books in the field of environment on Environmental Impact Assessment, Analytical Chemistry, C for Environmental Engineers, Climate Change and Weather Modification Technologies, Environmental Management - A primer. She has published about 20 papers in national and international referred journals. She is presently executing projects sponsored by MoEF, UNDP and NPC. She has carried out consultancy assignments for various national and state organizations in areas of environmental importance. She has been nominated as Associate Fellow by the AP Academy of Sciences for her contribution in the areas of environmental science and technology. Her areas of specialization include Environmental Impact Assessment and Numerical Modeling, Climate Change impacts, modeling and adaptations including Clean Development Mechanisms.

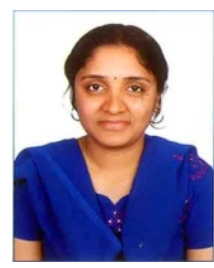

K. Shanti Sree was born in Andhra Pradesh, India in 1989 who has a master's degree in Environmental Science and Technology from Jawaharlal Nehru Technological University, Hyderabad 2011. She is presently working as a project associate in Environment Area at Administrative Staff College of India, Khairatabad, Hyderabad, AP. Her interests include working in the areas of climate change and geospatial technologies.



Iyyanki V. Murali Krishna was born in 1948 in Tamil Nadu, India, he is a $\mathrm{PhD}$ from Indian Institute of Science at Bangalore and $\mathrm{M}$ Tech from Indian Institute of Technology at Chennai is presently a consultant in the Environment Area of Administrative Staff College of India.

He worked as Director, Institute of Science and Technology and Coordinator of Centre for Atmospheric Sciences and Weather Modification Technologies at Jawaharlal Nehru Technological UniversityHyderabad. He started his career as Lecturer in Ocean Engineering centre at IIT Chennai in 1977 and joined National Remote sensing Agency at Hyderabad as Scientist (Oceanography) in 1979 and was head of Marine Applications Division at NRSA from 1982. He was a Guest Scientist at German Space Research Centre, Oberpfaffenhofen Germany and participated in MARSEN experiment at GKSS Centre at Geesthacht Germany during 1979 and also Visiting Professor at Chiba University, Chiba, Japan during the year 2000. He established Centre for Spatial Information Technology at JNTU and was Professor and Head of the centre for 15 years up to 2005. He has organized Workshops, Conferences and Conceived and implemented ICORG series and Training programs.

He is the recipient of Best Teacher Award in 2005 from Government of Andhra Pradesh. In recognition of his innovative and outstanding work in the field of Environmental and Civil Engineering, the Government State Centre presented "Engineer of the year award - 2008" on the occasion of 41th Engineers' Day Celebrations of Andhra Pradesh and The Institution of Engineers (India), Andhra Pradesh. 